\title{
The Auhtority of the Audit Board of The Republic Of Indonesia in Carrying Out Audits of Village Financial Management
}

\author{
Seviola Islaini*, Lalu Husni**, M.Ilwan** \\ *Law Master Student,Law Faculty Mataram University \\ **Lecture of law faculty Mataram University, Indonesia
}

\begin{abstract}
This study aims to determine the authority of the Audit Board of The Republic of Indonesia in carrying out audits of Village Financial Management. This research is a normative legal research with a statutory approach and conceptual approach. Based on the research results it is known that the inspection conducted by the Audit Board of The Republic of Indonesia covers all elements of state finance as stipulated in Law Number 17 of 2003, but village finance is not explicitly mentioned in the regulation. Referring to the approach used in formulating State Finances in a general explanation of Law Number 17 of 2003 concerning State Finances, can be said that finance managed by the village government is also included in the scope of state/regional finances which are also the object of Supreme Audit Board audit. This is related to the clarity of the status and legal certainty over villages in the constitution of the Republic of Indonesia. Village government as the lowest body of authority has the original authority to regulate its own household also has the authority and power as a gradual delegation of government over it ie the regional government and the central government, so that the central/regional government and village government is an inseparable part of government administration country. Therefore village finance is a state/regional financial subsystem as a consequence of the division of tasks among the government, regional government and village government.
\end{abstract}

Keywords : audit; village financial management

\section{Introduction}

The existence of normative juridical villages in Indonesia has been recognized according to the 1945 Constitution of the Republic of Indonesia (1945) before the amendment to the Elucidation of Article 18 states that in the territory of the Republic of Indonesia there are approximately 250 zelfbesturende landschappen and volksgemeenschappen such as villages in Java and Bali, nagari in Minangkabau, hamlets and clans in Palembang and so on. But after the amendment, the term village is no longer explicitly mentioned. Article 18B paragraph (2) of the 1945 Constitution states that the State recognizes and respects the customary law community units along with their traditional rights as long as they are still alive and in accordance with the development of society and the principles of the Unitary State of the Republic of Indonesia, which are regulated in the law.

Then in the new order a special arrangement was born regarding village governance, namely the enactment of Law Number 5 of 1979 concerning Village Government. This law places the centralization of village arrangements in the hands of the central government and the uniformity of village governance.

Then in the development when the reforms that occurred in 1998 there were major changes to the constitutional system in Indonesia. Regional autonomy as the demands of the community when it was welcomed and realized by the government with the birth of Law Number 22 of 1999 concerning Regional Government as amended by Law Number 32 of 2004 and has been replaced by Law Number 23 of 2014. Judging from the rationale for regulating villages, what is stipulated in Law Number 32 of 2004, is not much different from Law Number 22 of 1999. Regulations on village authority are delegated to regencies / cities, 
so that the stipulation is sufficient through Regency Regulations / City, but with due regard to recognition and respect for the village's origins and customs.

On January 15, 2014 with the passage of Law Number 6 of 2014 concerning Villages, it is hoped that all the interests and needs of village communities can be better accommodated. Villages are given greater opportunities to manage their own governance and equitable implementation of development is expected to improve the welfare and quality of life of rural communities, so that problems such as regional disparity, poverty, and other socio-cultural problems can be minimized.

It is different from the previous village regulation which only focuses on improving administrative aspects. The Village Law brings a breath of fresh air to the village administration, this raises the strengthening of authority and clarity of position for the village. From the aspect of authority, there are additional village authorities other than those based on original rights as recognized and respected by the state.

The Village Law provides flexibility in setting local scale authority and making decisions locally for the interests of village communities. This is explained through Articles 18 and 19 of the Village Law which emphasize that village authority encompasses authority in the area of village governance, implementation of village development, village community development, and empowerment of village communities based on community initiatives, rights of origin, and village customs, among others, authority based on original rights, local scale village authority, authority assigned by the government, provincial regional government, or district/city government, and other authority assigned by the government, provincial regional government, or district / city regional government in accordance with the provisions of the legislation.

The consequence of the increased authority allows the village to develop autonomy that is owned for the interests of the local community. To do this, the village government needs financial resources to carry out its functions and responsibilities to develop all the existing, newly emerging authorities, and a number of other authorities that may be assigned by the government, provincial government, or district government /city.

It is different from Law Number 5 of 1979 which states that the source of village income is the original village income, income that comes from the government and regional government, and other legal income. Article 72 of the Village Law states that more sources of village income, including original village income consisting of operating results, results of assets, self-help and participation, mutual cooperation, and other village original income, allocation of the State Budget and Expenditure, part of the results of regional taxes and levies district / city, the allocation of village funds that are part of the balance funds received by the district / city, financial assistance from the Provincial Revenue and Expenditure Budget and the District / City Revenue and Expenditure Budget, grants and donations that are not binding from third parties, and other legal village income.

The increasing number of village income sources will become the strength for the village government to manage, manage and organize their own households, as well as the burden of village responsibilities and obligations. The Village Law and its implementing regulations have mandated the village government to be more independent in managing the government and various natural resources it has, including the management of village finances and assets. Independence in terms of financial management is absolutely necessary for every village government so that the wheels of government in the village can run well.

In carrying out financial management, there are several principles of good financial governance. Article 2 of Minister of Domestic Affairs Regulation No. 20 of 2018 concerning Village Financial Management confirms that village finance is managed based on the principles of transparency, accountability, participation, and is carried out in an orderly and budgetary discipline. These principles are needed to realize village financial management that is free of corruption, collusion, effective, efficient and transparent and accountable, and can also strengthen the foundation of rural development implementation. Therefore the village government must be able to apply these principles in its governance.

Within the scope of state finances, the implementation of accountability and transparency is realized by the functioning and functioning of the auditor, or auditor of state finances. nesian Supreme Audit Institution as a state high institution that is independent of the influence and power of the government, was born through the 1945 Constitution which was subsequently confirmed by Law Number 17 of 2003 concerning State Finance and Law Number 15 of 2006 concerning the State Audit Agency. These laws and regulations provide a very high position in the Supreme Audit Board to maintain transparency and accountability in all aspects of state finances. As an independent state high institution, the Supreme Audit Board is tasked with examining the management and responsibilities of state finances carried out by the central government, regional 
governments, other state institutions, Bank Indonesia, State-Owned Enterprises, Public Service Bodies, Regional-Owned Enterprises, and institutions. or other body that manages state finances.

Village financial management is a new challenge facing the government. The financial audit used by the village government so far has been carried out as part of the examination of the Regional Government Financial Report with a test that is limited to distribution data only obtained from OPD in the District Government. Whereas in order to be more instrumental in encouraging village financial management to be more transparent, accountable and to prosper the village community, testing should be carried out to the management and evidence of accountability in the villages.

Based on Articles 2 and 3 of Law Number 15 of 2004 concerning the Audit of State Financial Management and Responsibility, the scope of the examination of the State Audit Board is the management and responsibility of state finances covering all elements of state finance as referred to in Article 2 of Law Number 17 of 2003 about State Finance. But village finance is not explicitly mentioned in the regulation.

Referring to the sources of village income it is known that most of the village finances come from the state budget and regional budgets which are part of the state finances. However, the village has other sources of income that are not derived from the state budget and regional budget such as village original income consisting of operating results, assets, self-help and participation, mutual assistance, and other village original income. So the question arises regarding the authority of the Supreme Audit Board in carrying out audits of village financial management.

\section{Research Methods}

This research is a normative legal research. The method used is the Statute Approach and Conceptual Approach. Sources and types of legal materials are primary legal materials, legal materials consisting of the 1945 Constitution of the Republic of Indonesia, Law Number 23 of 2014 concerning Regional Government, Law Number 6 of 2014 concerning Villages, Law Number 15 of 2006 concerning the Supreme Audit Board, Law Number 15 of 2004 concerning the Examination of Management and Responsibility for State Finances, Law Number 17 of 2003 concerning State Finance, and Minister of Home Affairs Regulation Number 20 of 2018 concerning Management of Village Finances. Then secondary legal materials, namely legal materials obtained from the opinions of scholars, journals, scientific works, and internet searches that are relevant to the issues raised, while tertiary legal material is legal material that is lifted from legal dictionaries and encyclopedias.

\section{Results And Discussion}

\section{Role and Authority of the Supreme Audit Board}

The authority has an important position in the study of constitutional law and state administration law. Once the importance of this position of authority, so F.A.M. Stroink and J.G. Steenbeek called it a core concept in state administration law and state administration law. ${ }^{1}$

According to the Big Indonesian Dictionary, the word authority is equated with the word authority, which is defined as the right and power to act, the power to make decisions, rule and delegate responsibility to other people/institution ${ }^{2}$. Meanwhile, according to Bagir Manan, authority in legal language is not the same as power. Power only represents the right to do and not do. At the same time authority means rights and obligations. $^{3}$

According to P. Nicolai as quoted by Aminuddin Ilmar, government authority is the ability to carry out certain legal actions or actions, that is actions or actions intended to cause legal consequences and include the emergence and disappearance of legal consequences. Furthermore, it was also stated that in the authority of the government the rights and obligations of the government in the actions or actions of the government were concluded. $^{4}$

Law Number 30 Year 2014 concerning Government Administration in Article 1 defines authority as the right owned by a Government Agency and/or Officer or other state administrator to take decisions and/or

\footnotetext{
${ }^{1}$ Ridwan HR, Hukum Administrasi Negara, Raja Grafindo Persada, Jakarta, 2013, p. 99

${ }^{2}$ Kamal Hidjaz, Efektivitas Penyelenggaraan Kewenangan Dalam Sistem Pemerintahan Daerah Di Indonesia, Pustaka Refleksi, Makasar, 2010, p, 35.

${ }^{3}$ Nurmayani, Hukum Administrasi Daerah, Penerbit UNILA, Bandar Lampung, 2009, p, 26.

${ }^{4}$ Aminuddin Ilmar, Hukum Tata Pemerintahan, Kencana, Jakarta, 2014, p, 102.
} 
actions in the administration of government while the authority of government is the authority of the Agency and/or Officer Government or other state administrators to act in the realm of public law.

Authority can be obtained through attribution, delegation, and mandate. Attribution is the granting of authority to a government agency or official by the 1945 Constitution of the Republic of Indonesia or the Law. Delegation is the delegation of authority from lower institutions or Government Officials with responsibility and accountability being fully transferred to the recipient of the delegation. Mandate is the delegation of authority from a higher Government Agency or Official to a lower Government Agency or Official with responsibility and accountability remaining with the mandator.

The 1945 Constitution in Article 23E paragraph (1) provides attribution authority to the Supreme Audit Board to conduct an examination of the management and responsibilities of state finances. According to Article 23 paragraph (1) of the 1945 Constitution, the management of state finances is embodied in the State Budget which is stipulated annually by law and carried out openly and responsibly for the greatest prosperity of the people. However, the definition of state finance is not explicitly contained in the provisions of Article 23 of the 1945 Constitution.

To understand the meaning of the term financial state can be given several interpretations, namely interpretation according to grammar (gramaticale interpretatie), according to history (historche interpretatie), according to systematics (systematische interpretatie) and according to the purpose of rules (teleologische interpretatie). From these various interpretations the term state finance must be interpreted restrictively, that is, only regarding the implementation of a state budget that has been approved by the House of Representatives. ${ }^{5}$ This is confirmed by the opinion that the definition of the revenue and expenditure budget referred to in the 1945 Constitution is only the State Budget (APBN) at the central level, so it is not covered by the Local government budget (APBD) which is not at all related to the duties and authority Audit Board of the Republic of Indonesia. ${ }^{6}$

After the amendment to the 1945 Constitution, the provisions concerning state finances and the management of state finances as well as the organizational structure and authority of the Supreme Audit Board changed fundamentally. Understanding of State Finances according to Article 23 after the third amendment of the 1945 Constitution is not only limited to the understanding of the State Budget, but also includes the Regional Budget. This is related to changes in the organizational structure and authority of the Supreme Audit Board, where in Article 23 of the 1945 Constitution the results of the financial audit by the Supreme Audit Board are not only submitted to the House of Representatives but also to the Regional Representative Council and the Regional Representative Council in accordance with their authority. ${ }^{7}$

Article $23 \mathrm{C}$ of the 1945 Constitution also states that other matters concerning state finances are regulated by law. Based on the mandate of the 1945 Constitution, Indonesia currently has Law Number 17 of 2003 concerning State Finance, in Article 1 it is stated that State Finance is all rights and obligations of the state that can be valued in money, as well as everything in the form of money. or in the form of goods that can be used as state property in connection with the implementation of these rights and obligations.

Furthermore, Article 2 states that state finances include the right of the state to collect taxes, issue and circulate money, and make loans, the state's obligation to carry out public service tasks and pay third party bills, state revenue, state expenditure, regional revenue, regional expenditure, state assets / regional assets that are managed by themselves or by other parties in the form of money, securities, accounts receivable, and other rights that can be valued with money, including assets that are separated in state/regional company companies, assets of other parties controlled by the government in the context of carrying out governmental duties and/or public interests, as well as the wealth of other parties obtained using facilities provided by the government.

To support the successful implementation of state government, management of state finances must be carried out in an orderly, obedient to the laws and regulations, efficient, economical, effective, transparent, and responsible with due regard for a sense of justice and propriety. One effort to realize transparency and accountability in the management of state finances is the existence of financial audits by independent and independent auditing bodies to examine management and accountability.

\footnotetext{
${ }^{5}$ Harun Alrasyid, Pengertian “Keuangan Negara” dalam Jurnal Hukum dan Pembangunan Vol. 25 No.2, 1995 , p, 128

${ }^{6}$ Jimly Asshiddiqie, Sengketa Kewenangan Antarlembaga Negara, Konstitusi Press, Jakarta, 2005

7 Arifin P. Soeria Atmadja, Keuangan Publik dalam Perspektif Hukum; Teori, Praktik, dan Kritik, Badan Penerbit Fakultas Hukum Universitas Indonesia, 2005
} 
Article 33 of Law Number 17 of 2003 concerning State Finances regulates that audits of management and accountability of state finances are regulated in a separate law, namely Law Number 15 of 2004 concerning Inspections of Management and Responsibilities of State Finances. The examination referred to in the law is the process of identifying problems, analysis, and evaluations carried out independently, objectively, and professionally based on inspection standards, to assess the truth, accuracy, credibility, and reliability of information regarding the management and financial responsibility of the State. The law also mandates the Supreme Audit Board to carry out audits of the management and responsibility of state finances. The examination carried out by the Supreme Audit Board covers all elements of state finance as stipulated in Act Number 17 of 2003.

The role of the Supreme Audit Board as auditors of the management and accountability of state finances is also regulated in Act Number 15 of 2006 concerning the State Audit Board which is mandated by Article 23G of the 1945 Constitution and also a substitute for Law Number 5 of 1973 concerning the State Audit Board which is deemed no longer in accordance with the development of the constitutional system. Article 6 paragraph (1) of the law states that the Supreme Audit Board is tasked with examining the management and responsibilities of state finances carried out by the Central Government, Regional Governments, other State Institutions, Bank Indonesia, State-Owned Enterprises, Public Service Agencies, Business Entities Regionally-owned, and other institutions or agencies that manage State finances.

\section{Position of Village Finance in the State Financial System}

All village rights and obligations that can be valued with money and everything in the form of money and goods related to the implementation of village rights and obligations are formulated as village finance through Article 71 of the Village Law. These rights and obligations then lead to income, expenditure, financing and village financial management.

Village income sources are regulated in Article 72 paragraph (1) of Law Number 6 of 2014, some of which are sourced from the State budget and Local government budget such as the allocation of the State Revenue and Expenditure Budget, part of the results of regional taxes and levies district / city, allocation village funds which are part of the balance funds received by the district/city, and financial assistance from the Provincial Local Government Budget and the Regency/City Local Government Budget.

Allocations sourced from the State budget and Local government budget are further elaborated in Government Regulation Number 47 of 2015 concerning Amendments to Government Regulation Number 43 of 2014 concerning Regulations for Implementing Law Number 6 of 2014 concerning Villages, including:

1. Article 95 which states that the government allocates Village Funds in the state revenue and expenditure budget each fiscal year intended for villages that is transferred through the regency/city regional revenue and expenditure budget;

2. Article 96 which states that the district/city regional government allocates in the district/city regional revenue and expenditure budget each budget year at least $10 \%$ (ten percent) of the balance funds received by the district/city in the regional income and expenditure budget after deducting special allocation funds;

3. Article 97 which states that the regency/city government allocates a portion of the proceeds of regency / city levies to the village at least $10 \%$ (ten percent) of the realization of the revenues from the regency/city levies; and

4. Article 98 which states that the provincial regional government and district/city regional government can provide financial assistance sourced from the provincial regional revenue and expenditure budget and the district/city regional revenue and expenditure budget to the village.

Even though the laws and government regulations on villages indicate that most of the sources of village finance come from the State budget and Local government budget, these provisions do not directly address the position of village finance in the state or regional financial system.

If it is related to the scope of state finances regulated in Law Number 17 of 2003 concerning State Finance in Article 2 including state and regional expenditures. Then in Article 3 paragraphs (4) and (5) of Law Number 1 of 2004 concerning the State Treasury, it is explained that all state expenditures, including subsidies and other assistance in accordance with the central government program, are financed by the State budget and all regional expenditures, including subsidies and other assistance in accordance with local 
government programs, financed with Local government budget. Then the source of village income derived from the allocation of the State Budget and State Budget and Regional Budget Revenues and Expenditures is included in the scope of state finances in the form of state expenditure and regional expenditure. But what about the sources of village income other than those originating from the allocation of the State Revenue and Expenditure Budget and the Regional Revenue and Expenditure Budget such as original village revenue consisting of operating results, asset yields, self-help and participation, mutual cooperation, and other village original income, grants and non-binding donations from third parties, as well as other valid village income.

If referring to several laws and regulations governing finance, namely Law Number 17 of 2003 concerning State Finance, Law Number 23 of 2014 concerning Regional Government, Law Number 33 of 2004 concerning Financial Balance Between the Central Government and Regional Government, Law No. 1/2004 concerning State Treasury and Law No. 15/2004 concerning the Audit of Management and Responsibility of State Finances, there is no chapter specifically regulating Village Finance.

The position of village finance in the state financial system can be answered by searching the legal system that governs the position of the village in the Republic of Indonesia's government system and relates it to the laws and regulations relating to the central/regional financial relationship with village finance.

The state is a social institution that has a territory and a ruling government supported by its citizens in the region in order to achieve certain goals. Philosophically, the state was founded with the aim of advancing the welfare of its people, protecting its people, and fulfilling the various interests of its people. This is in line with the views of philosophers about the purpose of the state. ${ }^{8}$

The formulation of state objectives is generally contained in the constitution. In Indonesia, the formulation of the state's objectives is contained in the Preamble to the 1945 Constitution, which is to protect the entire Indonesian nation and all of Indonesia's blood, promote public welfare, educate the nation's life, and participate in carrying out world order based on eternal peace and social justice. In this regard, the government as an organization is given the authority to carry out various tasks in order to achieve the objectives of the state and regulate everything related to the interests of the state. The way the government regulates and manages its tasks in realizing state objectives is always related to state finance as a form of financing for the administration of state government. Without state finances, it means that state objectives cannot be implemented so that they are only in the form of legal ideals. ${ }^{9}$

The Government system of the Republic of Indonesia places the president as the highest organizer of state government and at the same time the highest executor of the tasks of the state. These provisions are regulated in Article 4 paragraph (1) of the 1945 Constitution which states that the President of the Republic of Indonesia holds governmental authority according to the constitution. As part of government power, the president as Head of Government holds the power to manage state finances. The vast territory of the republic of Indonesia naturally requires the president to delegate the exercise of the authority of state financial management to the government apparatus at the central and regional levels.

The delegation of authority over financial management is a consequence of the implementation of Article 18 of the 1945 Constitution which divides the regions of Indonesia into autonomous regions. This is explicitly regulated in Article 6 of Law Number 17 Year 2003 concerning State Finance which states that the president as head of government holds the authority to manage state finances as part of the governmental authority handed over to the governor/regent/mayor as head of regional government to manage finances regions and represent regional governments in the ownership of separated regional assets. Furthermore, Article 2 of Law Number 33 Year 2004 states that the financial balance between the government and regional government is a sub-system of state finance as a consequence of the division of tasks between the government and regional governments. Both articles emphasize that regional finance is a subsystem of state finance.

The position of the village government in relation to decentralization and regional autonomy began to emerge after the issuance of Law Number 32 of 2004 concerning Regional Government. Article 206 of Law Number 32 Year 2004 states that governmental affairs which are under the authority of the village include existing governmental affairs based on the village's original right, governmental affairs which are the authority of the regency/city which are devolved to the village, co-administration tasks, the government

${ }^{8}$ Tim Bepeka, Keuangan Negara dan Badan Pemeriksa Keuangan, Sekretariat Jendral Badan Pemeriksa Keuangan, Jakarta, 1998, p. 7.

${ }^{9}$ Josef Mario Monteiro, Hukum Keuangan Negara dan Daerah, Setara Press, Malang, 2019, p. 10. 
provincial, and/or district/city government, other governmental affairs which are by law passed to the village.

But the village carries out more assistance tasks than running the affairs of its own village. This is due to village-related regulations that do not specifically pay attention to village authority, but rather give emphasis to the division of government affairs. These provisions position the village government as part of the district/city government. This is based on the stipulation of article 200 paragraph (1) which states that in the district/city regional government a village government is formed consisting of the village government and the village consultative body.

Then to place the village in an independent position and as a result of the evaluation of the implementation of Law Number 32 of 2004 which has not provided clarity about village authority, Law Number 6 of 2014 concerning Villages in Article 18 confirms that village authority includes authority in the field of implementation of village governance, implementation of village development, village community development, and empowerment of village communities based on community initiatives, origin rights, and village customs.

The granting of this authority must be followed by the transfer of resources to the village so that the authority possessed can be carried out properly. It is on this basis that villages have sources of village income as village rights which must then be managed as well as possible to carry out village obligations as reflected in the contents of the Village Budget.

Law Number 6 of 2014 concerning Villages forms the basis of village government regulation and financial management. Village financial management is part of village autonomy which provides a great opportunity for villages to manage their own governance and the implementation of development to improve the welfare and quality of life of village communities.

Law Number 6 of 2014 concerning Villages also reaffirms the status of the village as an inseparable part of the organizational structure of the regional government in the state government system, so that the village becomes the lowest arm of the state government functions formally based on Article 5 of the law which states that the village is domiciled in the Regency/City area, further clarification of the provisions explains that villages domiciled in the Regency/City area are formed in the system of state government as referred to in Article 18 of the 1945 Constitution of the Republic of Indonesia.

The village carries out government functions by referring to the provisions of Article 18 of the 1945 Constitution and spelled out in Law Number 6 of 2014 concerning Villages which stipulates that the village carries out government functions, both based on the original authority held by the village, as well as the authority assigned by the government, the provincial government, and district/city government.

The substance of the policy reflected in the provisions outlined above illustrates the interrelationship between the central/regional government and the village government as an inseparable part of the administration of the state government, all the administration of the village administration must be in line with the administration of the state government. Likewise, on the contrary, the administration of state government cannot rule out the administration of village government, including the administration of power in the management of village finances. So that village finance is a state/regional financial subsystem as a consequence of the division of tasks between the Government, regional governments and village governments.

\section{The Auhtority Of The Audit Board Of The Republic Of Indonesia In Carrying Out Audits Of Village Financial Management}

Law Number 15 of 2004 concerning the Audit of State Financial Management and Responsibility regulates that the examination of state finances includes an examination of the management of state finances and an examination of state financial responsibilities. The Audit Board has a constitutional authority to conduct audits of the management and responsibilities of state finances, so philosophically every state money used must be examined by the Audit Board.

Law Number 17 of 2003 concerning State Finance stipulates that state finances are all rights and obligations of the state that can be valued in money, as well as everything in the form of money or in the form of goods that can be used as state property in relation to the exercise of these rights and obligations.

If traced further on the general explanation of Law Number 17 of 2003 concerning State Finance which explains that the approach used in formulating State Finance is in terms of objects, subjects, processes, and objectives. 
In terms of objects referred to as State Finance include all rights and obligations of the state that can be valued in money, including policies and activities in the field of fiscal, monetary and management of separated state assets, as well as everything in the form of money, or in the form of goods that can be owned the state relates to the implementation of these rights and obligations. The position of the village administration in the Republic of Indonesia state government system is a unified legal system based on Article 1 number 2 of Law Number 6 of 2014 concerning Villages which states that the village administration is the administration of government affairs and the interests of the local community in the government system of the Unitary State of the Republic of Indonesia. The village is an extension of the functions of the central government administration.

From the subject matter, the meaning of State Finance covers all objects as mentioned above which are owned by the state, and / or controlled by the Central Government, Regional Governments, State/Regional Companies, and other bodies that are related to state finance. In connection with this explanation, Article 2 paragraph (1) of Law Number 23 Year 2014 concerning Regional Government which states that the Unitary State of the Republic of Indonesia is divided into provincial regions and provincial regions are divided into regency and city areas, subsequently in paragraph (2) it is stated that the regency/city area is divided into subdistricts and sub-districts divided into urban village and/or villages. The village is seen as the lowest unit of political community and government administration. As a result, the structure of a village government is no different than a government equivalent to a regional government with a structure that is adjusted, such as the executive and legislative functions, the election of village heads and so forth. ${ }^{10}$

In terms of process, State Finance covers the entire set of activities related to the management of objects as mentioned above, starting from the formulation of policies and decision making to accountability. The basis for the regulation and management of village finances by the village government is regulated in Minister of Domestic Affairs Regulation No. 20 of 2018 concerning Village Financial Management which is issued with consideration to carry out the provisions of Article 106 of Government Regulation Number 43 of 2014 concerning Implementation Regulations of Law Number 6 of 2014 concerning Villages as amended by Government Regulation Number 47 of 2015 concerning Amendment to Government Regulation Number 43 of 2014 concerning Regulations for Implementing Law Number 6 of 2014 concerning Villages. Article 1 number 6 of this stipulation states that Village Financial Management is the whole activity which includes the planning, implementation, administration, reporting and accountability of village finances.

Then in terms of objectives, State Finance includes all policies, activities and legal relations relating to ownership and / or control of the objects as mentioned above in the context of the administration of state government. The purpose of the stipulation of Village arrangements in Law Number 6 of 2014 concerning Villages is a further elaboration of the provisions referred to in Article 18 of the 1945 Constitution. Villages have original rights and traditional rights in regulating and managing the interests of local communities and playing a role in realizing the ideals of independence based on the 1945 Constitution.

Based on the description above, then the finance managed by the village government is also included in the scope of state/regional finances which are also the object of examination by the Audit Board. This is reinforced by the obligations of the village government in order to fulfill accountability for the management of village finances to account for and report on the implementation of the village government at the end of the fiscal year to the regents/mayors which will be used as evaluation material for the regents/mayors as a basis for guidance and supervision.

\section{Conclusion}

The birth of the Village Law No. 6 of 2014 increasingly provides clarity of status and legal certainty over the village in the constitutional system of the Republic of Indonesia. The Village Government as the lowest body of authority has the original authority to regulate its own household also has the authority and power as a gradual delegation from the government above it ie the regional government and the central government. This illustrates the relationship between the central/regional government and village government as an inseparable part of the administration of state government. The administration of the state government cannot rule out the administration of the village administration including in the case of the administration of power in the management of village finances. So that village finance is a state/regional financial subsystem

${ }^{10}$ Jimly Asshiddiqie, Gagasan Konstitusi Sosial, LP3ES, Jakarta, 2015, p, 353. 
as a consequence of the division of tasks between the Government, regional governments and village governments. If further related to the approach used in formulating State Finances in the general explanation of Law Number 17 of 2003 concerning State Finances, then finance managed by the village government is also included in the scope of state/regional finances which are also the object of auditing the Audit Board.

\section{References}

[1] Arifin P. Soeria Atmadja, 2005, Keuangan Publik dalam Perspektif Hukum; Teori, Praktik, dan Kritik, Badan Penerbit Fakultas Hukum Universitas Indonesia

[2] Aminuddin Ilmar, 2014, Hukum Tata Pemerintahan, Jakarta: Kencana

[3] Harun Alrasyid, 1995, Pengertian "Keuangan Negara” dalam Jurnal Hukum dan Pembangunan Vol. 25 No.2

[4] Jimly Asshiddiqie, 2015, Gagasan Konstitusi Sosial, Jakarta: LP3ES

[5] Jimly Asshiddiqie, 2005, Sengketa Kewenangan Antarlembaga Negara, Jakarta: Konstitusi Press

[6] Josef Mario Monteiro, 2019, Hukum Keuangan Negara dan Daerah, Malang: Setara Press

[7] Kamal Hidjaz, 2010, Efektivitas Penyelenggaraan Kewenangan Dalam Sistem Pemerintahan Daerah Di Indonesia, Makasar: Pustaka Refleksi

[8] Nurmayani, 2009, Hukum Administrasi Daerah, Bandar Lampung: Penerbit UNILA

[9] Ridwan HR, 2013, Hukum Administrasi Negara, Jakarta: Raja Grafindo Persada

[10] Soetardjo Kartohadikoesoemo, 1984, Desa, Jakarta: Balai Pustaka

[11] Tim Bepeka, 1998, Keuangan Negara dan Badan Pemeriksa Keuangan, Jakarta: Sekretariat Jendral Badan Pemeriksa Keuangan 